\title{
Transatlantica
}

Revue d'études américaines. American Studies Journal

\section{Ruth MILKMAN (ed). Organizing Immigrants: The Challenge for Unions in Contemporary California.}

Ithaca : Cornell University Press, 2000. 260 p.

\section{Dominique Daniel}

\section{OpenEdition}

Journals

Édition électronique

URL : http://journals.openedition.org/transatlantica/620

DOI : $10.4000 /$ transatlantica. 620

ISSN : 1765-2766

Éditeur

AFEA

Référence électronique

Dominique Daniel, «Ruth MILKMAN (ed). Organizing Immigrants : The Challenge for Unions in

Contemporary California. », Transatlantica [En ligne], 1 | 2003, mis en ligne le 27 mars 2006, consulté le

29 avril 2021. URL : http://journals.openedition.org/transatlantica/620 ; DOI : https://doi.org/10.4000/ transatlantica. 620

Ce document a été généré automatiquement le 29 avril 2021.

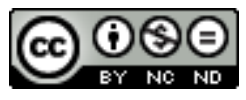

Transatlantica - Revue d'études américaines est mis à disposition selon les termes de la licence Creative Commons Attribution - Pas d'Utilisation Commerciale - Pas de Modification 4.0 International. 


\section{Ruth MILKMAN (ed). Organizing Immigrants : The Challenge for Unions in Contemporary California.}

Ithaca : Cornell University Press, 2000. 260 p.

\section{Dominique Daniel}

Organizing Immigrants, which is the result of a May 1998 conference at UCLA, is one of the first attempts to explore a domain that has received little academic attention as of today: the relations between immigrants and labor unions in the contemporary United States. California, the state which counts the largest number and proportion of workers of foreign origin in its labor force, is a fruitful framework for this undertaking. The contributors-mostly sociologists, an economist and a jurist-examine the sociodemographic profile of the "new" immigrant workers, analyze the political, economic and social factors that facilitate or hamper their organization and consider possible modes of organization.

2 Some of the articles offer general views of the situation in California. Lopez and Feliciano analyze California's "plural labor force", stressing the growing share of non white workers and the exceptional diversity of the new immigrants, in terms of ethnic origin, education and skills, as well as legal status. Although in California the preponderance of Mexicans is striking, there are workers of very diverse national origins. The most interesting contribution of the article is the stress put on the specificity of those immigrants. For example, the presence of illegal aliens is a condition rarely known earlier. Other articles in the book echo this analysis by assessing the effect of illegal status on the potential for unionization of the new labor force, some suggesting, in the wake of Hector Delgado's pioneering study, that it may not be as much of a handicap as expected.

3 Waldinger and Der-Martirosian then study the relationship between immigrant status and unionization, using Current Population Survey data and concluding on a pessimistic note about the likelihood of organizing poor, unskilled and recent immigrants. Sherman and Voss, for their part, approach the issue from the perspective 
of organized labor. They conduct a comparative analysis of tactical innovations by different locals to unionize immigrants and insist on the necessity of a complete reorganization and an opening toward other languages and cultures.

The hypotheses and conclusions presented in the first three contributions find illustrations in the remaining articles, which are case studies of recent organizing drives and labor movements in selected economic sectors of California (Wells, Bonacich, Zabin, Milkman and Wong, Fisk, Delgado): respectively the hotel industry in San Francisco, garment workers in Los Angeles, the drywallers' and ARE (a car wheel factory) strikes and the janitors' movement in Southern California. In some cases these movements were successful and highly publicized, thus disproving the common view that such workers are impossible to organize.

5 The obstacles, admittedly, are many. As hinted at in the volume's introduction, the general context of the 1980s and 1990s was very unfavorable to labor unions. The increased capital mobility in the manufacturing sector, both at the local and global levels, makes it easier for employers to boycott a factory where workers try to unionize; thus, in the garment industry, contracting out within and outside the United States is common practice. The lack of employment security, due to the seasonal or cyclical fluctuations of work, weakens employees. Illegal status and fear of deportation increases such vulnerability for some, although some articles offer evidence that undocumented workers tend to be more afraid of losing their jobs than of being deported.

6 Yet the articles put into relief the common characteristics that help explain the success of the movements: workers were very militant and leaders of their movement often benefited from union experience in their country of origin; there was strong solidarity between the strikers based on social and family ties from the home country and on collaboration with local churches and ethnic organizations; and they received substantial financial and legal assistance from organized labor.

7 Overall the book emphasizes both grassroots militancy among immigrant workers and the changing attitudes of American labor unions toward the newcomers ("bottom-up" and "top-down" approaches being both necessary). Published right after the new leadership of the AFL-CIO announced a renewal of organizing drives, it could not take into account the official reversal of the confederation's stance on immigrant workers in 2000 (for one of the first analyses of this, see Julie Watts, Immigration Policy and the Challenge of Globalization: Unions and Employers in an Unlikely Alliance (Cornell University Press, 2002)).

One of the conclusions that stands out in all the articles is that immigrants are not to blame for the unions' downturn of the last decades-on the contrary, they may be more eager to unionize, especially Latinos. The general conclusion, however, is mixed. The actions of the early 1990s demonstrated the potential and capacity for unionization of recent immigrant workers, but the hope of industry-wide organizing disappeared in the conservative and restrictionist mood of the rest of the decade, and organized labor so far has not taken significant strategic initiatives in favor of immigrants. The contributors offer the interesting hypothesis that the movements of the early $1990 \mathrm{~s}$ may have been due to the impact of the amnesty program under the 1986 Immigration Reform and Control Act, which offered immigrant workers more legal security and created a "window of opportunity" for labor activism. 
9 Nevertheless, the findings of the authors of this volume are only a beginning. This volume concentrates on California, which stands out in terms of the social characteristics of its immigrants and where the unionization rate of non native workers is much lower than the national average (see Waldinger's contribution); more research is therefore needed on other parts of the United States to assess the representativity of the Golden Gate state. Also, the bulk of the studies bears on workers of Mexican origin, with the notable exception of Wells' article which includes Asian and Latino workers. The lower propensity of Asians to unionize deserves a closer look. The specificity of female workers is not taken into account either. Finally more information on the general context which labor unions have to cope with would be useful: the inadequacy of labor legislation, the effects of globalization, the very nature of labor relations in the contemporary United States make it difficult to unionize any worker, regardless of their legal status. This calls for comparisons between immigrant and native workers' behaviors, so as to better assess the specificity of the case of non citizens in the workplace.

Yet this book provides a lot of "food for thought" on a all too often ignored topic. Very few other books adopt such a perspective at the crossroads of labor and immigration studies, and Organizing Immigrants invites us to follow this route. It therefore decisively lays the groundwork for fruitful research.

\section{AUTEUR}

DOMINIQUE DANIEL

Université de Tours 